13. Рубинчик Ю.А. Фонетико-графические изменения арабских заимствований и отражение их в словарях персидского языка. Ираноафразийские языковые контакты. Москва : Наука, 1987. С. 125-132.

14. Сепир Э. Язык. Введение в изучение речи / пер. с англ. А.М. Сухотин. Москва-Ленинград : Соцэкгиз, 1934. 467 с.

15. Тимофеева Г.Г. Английские заимствования в русском языке (фонетико-орфографическая ассимиляция) : автореф. дисс. ... д-ра. филол. наук : 10.02.02. Санкт-Петербург, 1992. 30 с.

УДК $811.111-342$

DOI: $10.24144 / 2617-3921.2020 .18 .34-46$

Валентина Жук

старший викладач кафедри граматики факультету романо-германської філології, Одеський національний університет імені I.I. Мечникова orcid.org/0000-0002-1767-1922

Одеса, Украӥна, тел. +0661740247 ragsphoto@ukr.net

\title{
Англійські категоріальні пасивні конструкції в синхронії та діахронії
}

Анотація. Проблема пасивного стану в англійській мові привертає увагу лінгвістів на протязі довгого періоду часу. Об'єктом дослідження є одиниці різних рівнів мови, які використовуються для передачі значення пасивності в англійській мові. Мета роботи полягає в структуруванні функиіонально семантичного поля пасивності в англійській мові, в вивченні пасивних конструкцій в історичній ретроспективі протягом всього ново англійського періоду, а також у виявленні функиій пасиву в текстах різних типів дискурсу. Різні аспекти цієї категорії досить добре вивчені, проте багато моментів, як і раніше залишаються предметом наукової дискусї. Складність розкриття значення пасиву складається в неоднорідності його семантики, для розуміння якого необхідний облік різних мовних рівнів. Мовні засоби різних рівнів, які виражають одне значення, є пов'язаними певними відносинами, завдяки яким утворюються функиіонально-семантичні поля. У нашій роботі дослідженню піддається функиіонально семантична категорія пасивності, яка репрезентується не тільки морфологічними, а й лексико-семантичними засобами. Пасивність же розглядається нами як заставне значення, при якому процесуальний ознака привноситься ззовні. У своїй роботі ми 
звертаємося до структурування функиіонально-семантичного поля пасивності в сучасній англійській мові, яке має свій центр $і$ периферію. В результаті аналізу частотності вживання категоріальних засобів вираження пасивності в сучасній англійській мові кіния XX-початку XXI cm. нами були отримані дані, які свідчать, щуо пряма пасивна конструкція становить 54,08\% від загального числа прикладів категоріальних засобів вираження пасивності в сучасній англійській мові кінця XX-початку XXI cm., за рахунок збільшення кількості інших типів пасивних конструкцій; кількість прямих пасивних конструкиій зменшилася, але вони як $і$ раніше $\epsilon$ самими частотними. Таким чином, в ході нашого дослідження, виявлено, щзо всі типи пасивних конструкиій категоріальних засобів вираження пасивності виявилися досить рухливими. Необхідно також підкреслити, щуо в ранній ново англійській мові зустрічаються категоріальні пасивні конструкиії всіх типів, изе свідчить про вже сформовані пасивні конструкиії в зазначений період. Крім того, динаміка змін по тимчасовим відрізкам підтверджує зростання частотності вжсвання пасивних конструкиій до кіния XIX-nочатку XX сm. В англійській літературі кіния XX-початку XXI cm. навпаки спостерігається яскраво виражена і досить чітко реалізується тенденція до зниження частки пасиву в дієслівній системі. Також отримані дані представлені в вигляді таблиці 1 (необхідно нагадати, щуо зазначені числові дані - цее відношення кількості прикладів до числа проаналізованих сторінок). Отримані результати дозволяють нам говорити про зміни, щуо відбулися в системі категоріальних засобів вираження пасивності.

Ключові слова: історичний період, пасивність, прийменниковий тип, суб'єктно-предикативний тип, безособовий тип, післялог.

Abstract. The problem of passive voice in the English language has attracted the attention of linguists over a long period of time. The object of the study is the units of different levels of the language used to convey the meaning of passivity in the English language. The purpose of the work is to structure the functionalsemantic field of passivity in the English language, to study passive constructions in historical retrospective throughout the New English period, and also to identify the functions of the liability in texts of various types of discourse. Various aspects of this category are well studied, however, many points remain the subject of scientific discussion. The difficulty of disclosing the meaning of a liability is the heterogeneity of its semantics because the understanding of which it is necessary to take into account various language levels. Linguistic means of various levels, expressing one meaning, are connected by certain relations, due to which functional-semantic fields are formed. So, an analysis of the frequency of using categorical means of expressing passivity in the early New English language showed that, the direct passive construction is the most commonly used means, accounting for $87.3 \%$ of the total number of examples of categorical means of passivity. As can be seen from the chart, direct passive constructions predominate numerically, accounting for $79 \%$ of 
the total number of categorical means of expressing passivity in English in the late $X I X^{\text {th }}$ - early $X X^{\text {th }}$ centuries, i.e. direct passive structures are still the most frequent, but their number has decreased due to an increase in the number of other types. It must be emphasized that in the early New English language there are categorical passive constructions of all types, this indicates the already formed passive constructions in the indicated period. In addition, the dynamics of changes in time periods confirms the increase in the frequency of use of passive structures by the late XIX ${ }^{\text {th }}$ - early XX $X^{\text {th }}$ centuries. In English literature of the late $X X^{\text {th }}$-early XXI ${ }^{\text {st }}$ centuries, on the contrary, there is a pronounced and quite clearly realizing tendency to a decrease in the share of liability in the verb system. Also, the obtained data are presented in the chart (it must be recalled that the indicated numerical data is the ratio of the number of examples to the number of pages analyzed). The results obtained allow us to talk about the changes that have occurred in the system of categorical means of expressing passivity.

Keywords: historical period, passive, prepositional type, sub-predicate type, impersonal type, postposition.

Вступ. Ця стаття присвячена комплексному дослідженню системи категоріальних засобів вираження пасивності в англійській мові в текстах трьох історичних періодів. Проблема пасивного стану в англійській мові привертає увагу лінгвістів на протязі довгого періоду часу $[2 ; 3 ; 4 ; 5 ; 7]$. Різні аспекти цієї категорії досить добре вивчені, проте багато моментів, як і раніше залишаються предметом наукової дискусії. Складність розкриття значення пасиву складається в неоднорідності його семантики, для розуміння якого необхідний облік різних мовних рівнів. Мовні засоби різних рівнів, які виражають одне значення, $є$ пов'язаними певними відносинами, завдяки яким утворюються функціонально-семантичні поля. У нашій роботі дослідженню піддається функціонально семантична категорія пасивності, яка репрезентується не тільки морфологічними, а й лексико-семантичними засобами. Пасивність же розглядається нами як заставне значення, при якому процесуальний ознака привноситься ззовні. У своїй роботі ми звертаємося до структурування функціонально-семантичного поля пасивності в сучасній англійській мові, яке має свій центр і периферію.

Ця стаття присвячена комплексному дослідженню системи категоріальних засобів вираження пасивності в англійській мові в текстах трьох історичних періодів, а також їх дискурсивно-прагматичного потенціалу і ролі в створенні текстів різних дискурсів. В ході роботи ми детально вивчили дослідження, присвячені історії розвитку пасивного стану та пасивних конструкцій в англійській мові $[1 ; 6 ; 8 ; 10 ; 11 ; 12 ; 13 ; 14]$.

Актуальним також, на наш погляд, є вивчення ролі засобів вираження пасивності в побудові текстів деяких типів дискурсу, не вивчених до сих пір 3 цього боку. Встановлення тексто- та стильового потенціалу різнорівневих пасивних конструкцій, виявлення функцій пасивних структур в текстах різних 
дискурсів, представляються нам важливими та необхідними для розширення уявлення про механізми текстотворення.

Об'єктом дослідження $є$ одиниці різних рівнів мови, які використовуються для передачі значення пасивності в англійській мові. Мета роботи полягає в структуруванні функціонально семантичного поля пасивності в англійській мові, в вивченні пасивних конструкцій в історичній ретроспективі протягом всього ново англійського періоду, а також у виявленні функцій пасиву в текстах різних типів дискурсу. Матеріалом для нашого дослідження послужили речення 3 категоріальними пасивними конструкціями, відібрані шляхом суцільної вибірки 3 художніх творів англомовних авторів трьох періодів: кінця XVI - початку XVII столітть (Вільям Шекспір, Френсіс Бекон, Томас Мор), кінця XIX - початку XX ст. (Джордж Макдональд, Джеймс Монтегю Родс, Оскар Уальд) та кінця XX початку XXI ст. (Сер Теренс Девід Джон Пратчетт, Джон Рональд Руел Толкін, Джоан Роулінг, Крістофер Паоліні, Стефані Маєр, Мег Кебот). Загальний обсяг проаналізованого матеріалу становить: рання ново англійська мова - 809 сторінок, сучасна англійська мова кінця XIX - початку XX ст. - 405 сторінок та сучасна англійська мова кінця XX - початку XXI ст. - 3306 сторінки.

Методологія та методи дослідження. В якості основного методу дослідження в дисертації використовується метод «польового структурування», що сприяє визначенню компонентного складу функціонально-семантичного поля пасивності. Застосовуються також гіпотетико-дедуктивний метод та метод трансформації.

Виклад основного матеріалу дослідження. Вибираючи періоди розвитку англійської мови, ми брали до уваги їх наступні характеристики: ранньо ново англійський період XVI - XVII ст. - це епоха, яка характеризується англійським літературним відродженням та становленням англійської національної літературної мови, на відміну від мови цього періоду, що характеризується відсутністю однаковості мовної норми, мова періоду кінця XIX - початку XX ст. відрізняється певною стандартизацією, а англійська мова кінця XX - початку XXI ст. - це те, з чим ми маємо справу безпосередньо 3 дня на день [9; 15]. Таким чином, при аналізі художніх текстів ми враховуємо хронологічний фактор, розглядаючи три тимчасових зрізу: ранньо ново англійська та два зрізу сучасної англійської мови.

Розглянемо категоріальні пасивні конструкції. Згідно 3 нашим дослідженням, загальний обсяг категоріальних пасивних структур становить 512 прикладів в ранньо ново англійській мові, 567 - в англійській мові кінця XIX - початку XX ст. та 3726 прикладів в сучасній англійській мові кінця XX - початку XXI ст.

В англійській мові розрізняються п'ять типів пасивних конструкцій, які залежать від того, якому доповненню активної структури відповідає підмет пасивної конструкції. Таким чином, виділяють пряму, непряму, прийменникову, суб'єктно предикативну та безособову пасивні структури. 
Кожен тип описується в трьох часових періодів: ранній ново англійській XVI - XVI ст., сучасній англійській кінця XIX - початку XX ст. та сучасній англійській мові кінця XX - початку XXI ст. Дослідження та ретельний аналіз матеріалу проводився на художніх творах зазначених періодів.

Розглянемо окремо кожен тип категоріальної пасивної конструкції в трьох часових зрізах.

1. Пряма пасивна конструкція. Пряма пасивна структура утворена від дієслова, здатного управляти прямим доповненням, відповідним підмету в пасивній конструкції та позначає паціенс дії. Розглянемо приклад:

Thy substance, valued at the highest rate, Cannot amount unto a hundred marks; Therefore by law thou art condemn'd to die. (Shakespeare). У прикладі присудок виражений дієсловом у формі пасивного стану, а підмет є паціенс дії.

В ході аналізу вживання прямих пасивних конструкцій в досліджуваних періодах ми брали до уваги співвідношення кількості прикладів до числа проаналізованих сторінок, так як на всіх історичних зрізах було проаналізовано різну кількість сторінок. Отже, в ранній новоанглійській мові нам зустрілося 407 речень 3 прямою пасивною конструкцією на 809 сторінках, в англійській мові кінця XIX - початку XX ст. - 355 прикладів на 405 сторінках та в сучасній англійській мові кінця XX - початку XXI ст. - 2015 прикладів на 3306 сторінках.

У ході статистичної обробки отримані дані, які представимо у вигляді гістограми (див. мал 1.).

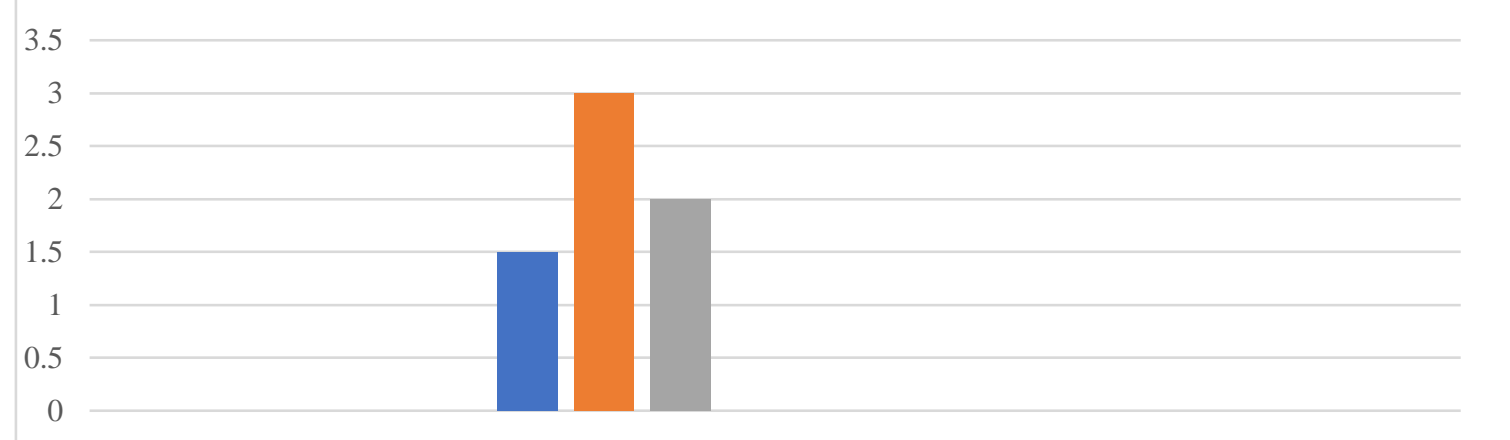

Мал. 1. Частотність вживання прямих пасивних конструкцій в текстах художнього дискурсу в досліджуваних історичних періодах

1.5 - рання ново англійська мова XVI - XVI ст.

3 - сучасна англійська мова кінця XIX - початку XX ст.

2 - сучасна англійська мова кінця XX - початку XXI ст. 


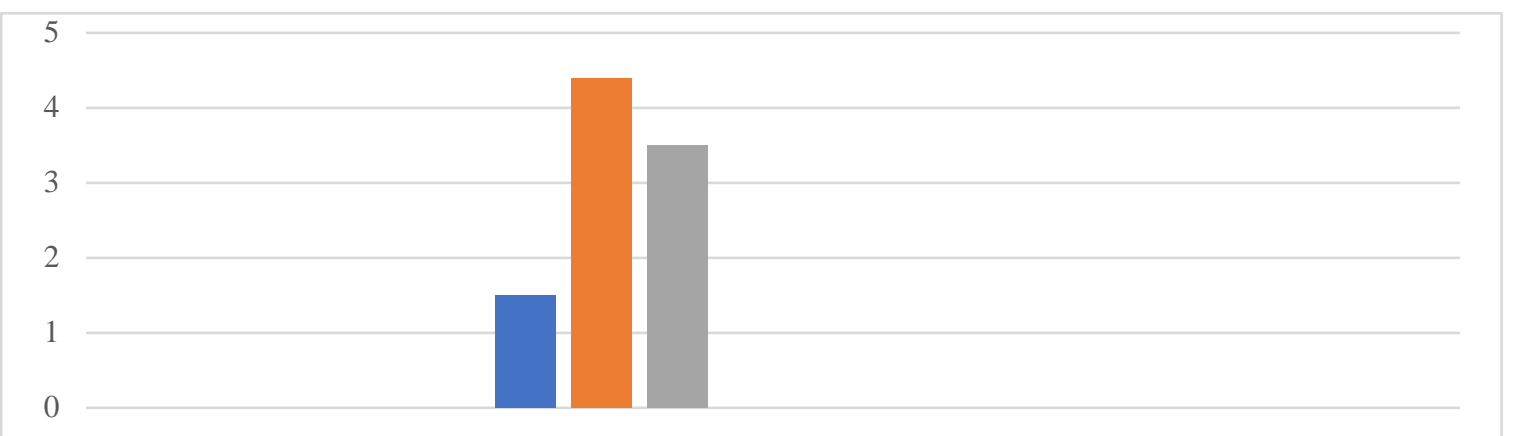

Мал. 2. Частотність вживання непрямих пасивних конструкцій в текстах художнього дискурсу в досліджуваних історичних періодах

1.5 - рання ново англійська мова XVI - XVI ст.

4.5 - сучасна англійська мова кінця XIX - початку XX ст.

3.5 - сучасна англійська мова кінця XX - початку XXI ст.

Як видно з гістограми 1, відбувається збільшення частотності вживання прямих пасивних конструкцій до кінця XIX - початку XX ст., а потім зменшення до початку XX - кінця XXI ст. Розглянемо інші типи категоріального пасиву.

2. Непряма пасивна конструкція. Непрямий пасив утворюється від дієслова, який управляє прямим та непрямим доповненнями. У непрямій пасивної конструкції підмет відповідає непрямому доповненню в активній структурі. Цей компонент $є$ бенефіціантом дії на семантичному рівні. Значущою структурною ознакою непрямого пасиву $є$ присутність прямого доповнення, яке передає значення паціенс дії, наприклад:

It was not given me, nor I did not buy it. (Shakespeare)

У наведеному прикладу можемо спостерігати паціенс дії, виражений прямим доповненням. Як і в випадку з прямою пасивною конструкцією, в ході аналізу розвитку непрямої пасивної конструкції в досліджуваних періодах ми брали до уваги співвідношення кількості прикладів до числа проаналізованих сторінок.

Таким чином, в ранній новоанглійській мові нам зустрілося 21 речення 3 непрямою пасивною структурою на 809 сторінках, в англійській мові кінця X1X - початку XX ст. - 40 прикладів на 405 сторінках та в сучасній англійській мові кінця XX - початку XXI ст. - 550 прикладів на 3306 сторінках. Дані, отримані в ході статистичної обробки, представимо у вигляді гістограми (див. мал. 2).

3 гістограми 2 випливає, що частотність вживання непрямого пасиву збільшилася до кінця XIX - початку XX ст., і зменшилася до початку XX кінця XXI ст. Той факт, що непрямий пасив вже зустрічається в ранній ново англійській, говорить про сформованість цього типу в зазначений період.

\section{3. Прийменникова пасивна конструкція.}

Прийменниковим пасивом вважаються структури, в яких підмет відповідає прийменниковому доповненню в активній конструкції, а для 
прийменнику, який вживається за дієсловом в формі пасивного стану, ми приймаємо термін «післялог».

The Duke's in council, and your noble self, I am sure, is sent for. (Shakespeare)

'A whipping master should be sent for,' said Don Pedro wearily, and he went back to the terrace. (O. Wilde)

This was a life and death matter, though, and no moment to worry about being laughed at. (Rowling)

Дані приклади підтверджують, що підлягає прийменникового пасиву позначає паціенс. Як і в попередніх випадках, для більш точного аналізу розвитку прийменникової пасивної конструкції обчислюємо співвідношення кількості прикладів до числа проаналізованих сторінок. Таким чином, в ранній ново англійській мові нам зустрілося 13 речень 3 прийменниковою пасивною конструкцією на 809 сторінках, в англійській мові кінця XIX - начала XX ст. - 30 прикладів на 405 сторінках і в сучасній англійській мові кінця XX початку XXI ст. - 470 прикладів на 3306 сторінках.

Отримані дані представимо у вигляді гістограми (див. мал. 3).

3 гістограми 3 виходить, що частотність вживання прийменникових пасивних конструкцій значно збільшилася до кінця XX - початку XXI ст. Тому, що обов'язковою ознакою прийменникового пасиву, який діагностує тип пасивної конструкції, $є$ післялог, вважаємо за необхідне його проаналізувати. У сучасній англійській мові в реченні 3 прийменниковим пасивом дієслово вживається з різними післялогами. Наведемо приклади:

to look' Loose me, she cried, and let me go. For thou hast named what should not be named, and shown the sign that may not be looked at. (O. Wilde)

'Oh yes. But I'm sure he will then be looked after by someone who is, shall we say, better capable of translating his little barks along more traditional lines?' (Ptatchett)

to speak 'I will not be spoken to like that!' said Uncle Vernon, trembling with rage. (Rowling)

'Twere good she were spoken with; for she may strew Dangerous conjectures in ill-breeding minds. (Shakespeare)

Наведені приклади можуть слугувати підтвердженням того, що дієслова, які вживаються з різними післялогами, передають різні значення.

\footnotetext{
Мал. 3. Частотність вживання прийменникових пасивних конструкцій в текстах художнього дискурсу в досліджуваних історичних періодах
} 
0.5 - рання ново англійська мова XVI - XVI ст.

1 - сучасна англійська мова кінця XIX - початку XX ст.

5 - сучасна англійська мова кінця XX - початку XXI ст.

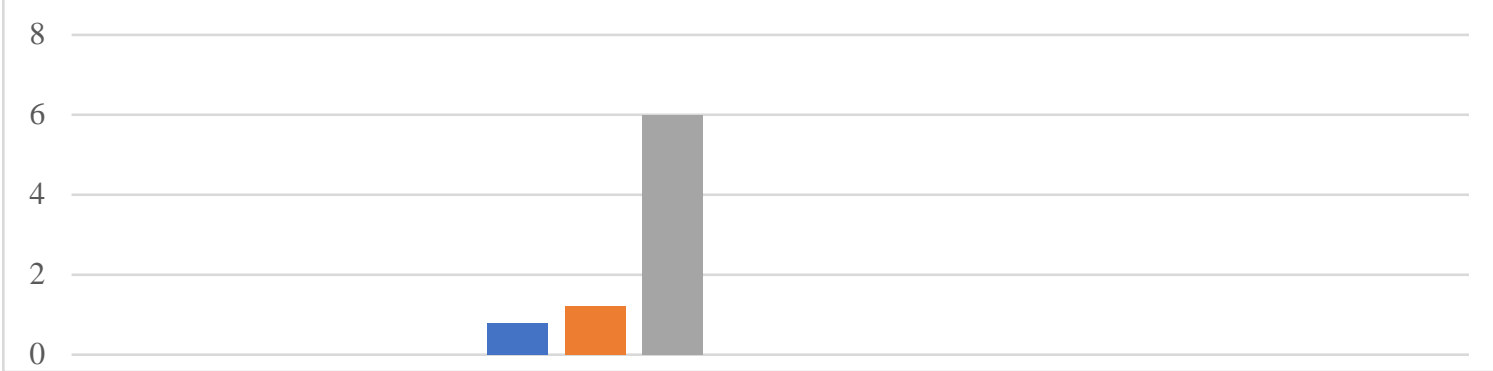

Мал. 4. Частотність вживання суб'єктно-предикативних конструкцій в текстах художнього дискурсу в досліджуваних історичних періодах

0.9 - рання ново англійська мова XVI - XVI ст.

1.2 - сучасна англійська мова кінця XIX - початку XX ст.

6 - сучасна англійська мова кінця XX - початку XXI ст.

4. Суб'сктно-предикативна пасивна конструкція. Досить широке поширення в англійській мові отримала суб'єктно-предикативна пасивна конструкція, яка вживається 3 дієсловами, що зустрічаються в активних структурах об'єктно-предикативної конструкції. Відзначено, що підмет досліджуваної пасивної конструкції відповідає іменному компоненту об'єктно-предикативної структури. Наведемо приклади: Dangerous conceits are in their nature poisons, Which at the first are scarce found to distaste. (Shakespeare)

Значущим для визначення типу пасивної структури в даній пасивній конструкції $\epsilon$ суб'єктно-предикативний член, який може розглядатися як частина присудка разом з дієсловом в пасивному стані, у зв'язку з тим, що він передає значення дії. Судячи 3 наших даних, можна говорити про досить широкій вжиток пасивної конструкції описуваного типу в досліджуваних періодах. У ранній ново англійській мові нам зустрілося 49 речень 3 вказаною пасивною структурою на 809 сторінках, в англійській мові кінця XIX - початку XX ст. - 77 прикладів на 405 сторінках і в сучасній англійській мові кінця XX - початку XXI ст. - 612 прикладів на 3306 сторінках. Уявимо результати в гістограмі (див. мал. 4).

Як видно з гістограми 4, в сучасній англійській мові кінця XX - початку XXI ст. значно збільшується число суб'єктно-предикативних конструкцій, а в сучасній англійській мові кінця XIX - початку XX ст. спостерігається помітний спад частотності зазначеної конструкції, хоча частотність вживання суб'єктно-предикативних пасивних конструкцій змінилася незначно протягом трьох періодів.

Структура суб'єктно-предикативної пасивної конструкції включає підмет, виражений субстантівним компонентом, дієслово в формі пасивного стану, а також суб'єктно-предикативний член, який є невід'ємною частиною зазначеної пасивної конструкції. У зв'язку з тим, що суб'єктно-предикативний 
член має найрізноманітніше вираження протягом досліджуваних нами періодів, а також зазнав істотних змін, ми порахували важливим проаналізувати способи його вираження. Наше дослідження раннього ново англійського і двох сучасних періодів показало, що суб'єктно-предикативний член може бути виражений:

1) іменником: Our clemency would be thought cruelty. (Jonson)

2) інфінітивом: Money was made to work, to move, to grow, not to be locked up in some vault. (Pratchett)

3) прикметником: And your boast shall be made vain. (Tolkien)

4) причастям II: Mountain trolls can occasionally be seen mounted on Graphorns, though the latter do not seem to take kindly to attempts to tame them and it is more common to see a troll covered in Graphorn scars. (Rowling)

5) поєднанням «аs + прикметник»: Being intelligent and capable of speech, it should not stricdy speaking be termed a beast, but by its own request it has been classified as such by the Ministry of Magic. (Rowling)

6) поєднанням «аs + іменник»: A man who rushes into a burning building to rescue a stupid cat and comes out carrying the cat is seen as a hero, even if he is a rather dumb one. (Pratchett)

Таким чином, суб'єктно-предикативний член, який $є$ невід'ємною частиною зазначеної пасивної конструкції, має досить різноманітне вираження.

\section{5. Безособова пасивна конструкція}

Безособовий пасив, який отримав порівняно невелике поширення в англійській мові, це пасивна конструкція, де підмет - це безособове формальне $i t$.

It is said in the Annals of Beleriand that 'the gates of Morgoth were but one hundred and fifty. (Tolkien)

It is written, they appear to men like angels of light; light is an effect of fire, and fire will burn; ergo, light wenches will burn. (Shakespeare)

Дані приклади підтверджують, що обов'язковим структурним фактором безособової пасивної конструкції $є$ підрядне речення, яке може бути кваліфіковано як пряме доповнення, на глибинному рівні позначає паціенс дії; підлягає же вважається безособове формальне it зі значенням амбієнтне.

Безособова пасивна конструкція не відрізняється високою частотністю як в ранній ново англійській, так і в сучасних англійських періодах. Отже, в ранньо ново англійській мові нам зустрілося 22 речення 3 безособовою пасивною структурою на 809 сторінках, в англійській мові кінця XIX-початку XX ст. - 65 прикладів на 405 сторінках і в сучасній англійській мові кінця XX - початку XXI ст. - 79 прикладів на 3306 сторінках. Отримані дані представлені в гістограмі (див. мал. 5). 


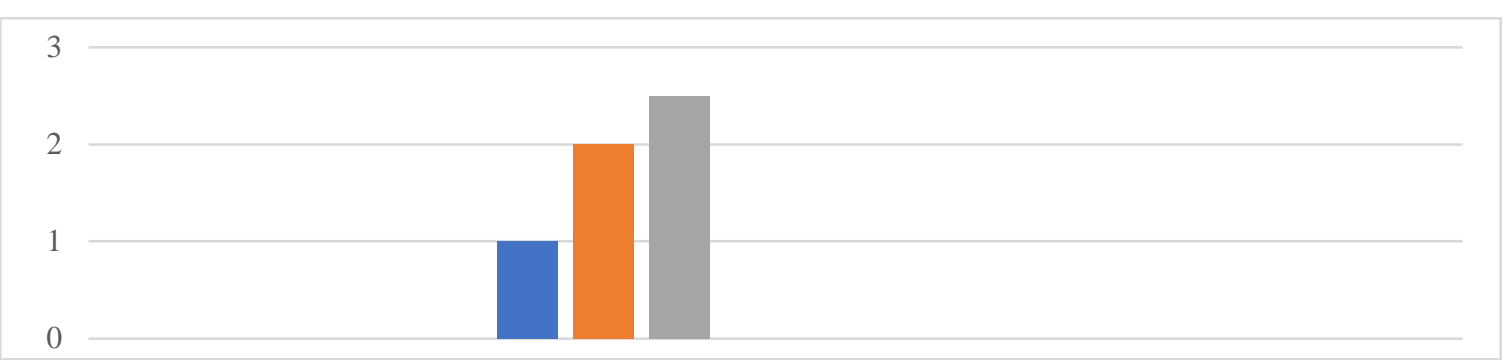

Мал. 5. Частотність вживання безособових пасивних конструкцій в текстах художнього дискурсу в досліджуваних історичних періодах

1 - рання ново англійська мова XVI - XVI ст.

2 - сучасна англійська мова кінця XIX - початку XX ст.

2.5 - сучасна англійська мова кінця XX - початку XXI ст.

Таблиця 1. Частотність вживання різних типів пасивних конструкцій категоріальних засобів вираження пасивності в текстах художнього дискурсу в досліджуваних історичних періодах

\begin{tabular}{|c|c|c|c|c|c|c|c|}
\hline $\begin{array}{l}\text { Історич- } \\
\text { ний } \\
\text { період }\end{array}$ & $\begin{array}{l}\text { Частотність } \\
\text { Тип } \\
\text { конструкції }\end{array}$ & $\begin{array}{c}\text { Прямі пасивні } \\
\text { конструкції }\end{array}$ & $\begin{array}{c}\text { Прямі пасивні } \\
\text { конструкції }\end{array}$ & $\begin{array}{c}\text { Прийменникова } \\
\text { пасивна } \\
\text { конструкція }\end{array}$ & $\begin{array}{c}\text { Суб'єктно- } \\
\text { предикативна } \\
\text { пасивна } \\
\text { конструкція }\end{array}$ & $\begin{array}{l}\text { Безособова } \\
\text { пасивна } \\
\text { конструкція }\end{array}$ & всього \\
\hline \multirow{2}{*}{$\begin{array}{l}\text { XVI- } \\
\text { XVII }\end{array}$} & абсолютна & 407 & 21 & 13 & 49 & 22 & \multirow{2}{*}{$\begin{array}{c}512 \\
100 \%\end{array}$} \\
\hline & відносна & 79,5 & 4,1 & 2,54 & 9,57 & 4,29 & \\
\hline \multirow{2}{*}{$\begin{array}{l}\text { XIX- } \\
\text { XX }\end{array}$} & абсолютна & 355 & 40 & 30 & 77 & 65 & \multirow{2}{*}{$\begin{array}{r}567 \\
100 \%\end{array}$} \\
\hline & відносна & 62,61 & 7,05 & 5,3 & 13,58 & 11,46 & \\
\hline \multirow{2}{*}{$\begin{array}{l}\text { XX- } \\
\text { XXI }\end{array}$} & абсолютна & 2015 & 550 & 470 & 612 & 79 & \multirow{2}{*}{$\begin{array}{r}3726 \\
100 \%\end{array}$} \\
\hline & відносна & 54,08 & 14,76 & 12,62 & 16,42 & 2,12 & \\
\hline
\end{tabular}

Ми бачимо, що в XX - XXI ст. в нашому матеріалі відмічено зростання частотності вживання безособових пасивних конструкцій в порівнянні з XVI XVII ст., проте, на початку XIX - кінці XX ст. зареєстрований незначний спад (див. табл. 1). Як було сказано вище, підрядне речення $\epsilon$ обов'язковим членом безособової пасивної структури. Це підрядне речення, в свою чергу, може бути приєднано до головного при допомоги різних сполучників. В ході дослідження, нами виявлено такі сполучники та сполучні слова:

that: It be thought that you enjoy any true pleasure. (Jonson)

It is written that the shoemaker should meddle with his yard and the tailor with his last, the fisher with his pencil and the painter with his nets. (Shakespeare)

how: It is considered how it worked. (Pratchett)

what: It might have been seen what feeling we bore. (Shakespeare)

Можна припустити, що це неповний список сполучників та сполучених слів. 
Крім того, в ході дослідження, нами були виявлені випадки безсполучникового приєднання підрядних додаткових до головного речення 3 безособовим формальним підметом, вираженим it, наприклад: It is concluded: Banquo, thy soul's flight, If it find heaven, must find it out tonight. (Shakespeare)

Аналіз показав, що безсполучникове приєднання - явище, яке досить широко вживається в англійській мові.

Висновки 3 дослідження. Таким чином, встановлено, що в англійській мові XVI - XVII ст. зустрічаються п'ять типів категоріальних пасивних структур, які вживаються і в сучасній англійській мові, а саме: прямий, непрямий, прийменниковий, суб'єктно-предикативний, безособовий типи пасивних конструкцій. Відзначимо, що крім підмету пасивної структури мають місце i інші компоненти, що діагностують тип пасиву. Перерахуємо їх: для непрямої пасивної конструкції значний інтерес представляє пряме доповнення, для прийменникової пасивної структури - післялог, для суб'єктно-предикативного пасиву - суб'єктно-предикативний член, а в безособовій пасивній конструкції важливе місце займає пряме доповнення, яке виражено підрядних реченнями. В ході дослідження було виявлено, що кожен тип пасивної структури виявляє саму різну частотність вживання в ранній ново англійській мові XVI - XVII ст., сучасній англійській кінця XIX - початку XX ст. та в сучасній англійській кінця XX - початку XXI ст. Найбільш частотним протягом трьох синхронних зрізів є прямий пасив, приклади якого склали близько 80\% від загальної кількості прикладів категоріальних засобів вираження пасивності. Частотність непрямої, безособової, суб'єктно-предикативної пасивних структур залишається дуже низькою порівняно з прямим пасивом.

Отже, аналіз частотності вживання категоріальних засобів вираження пасивності в ранній ново англійській мові показав, що, як вже було заявлено, пряма пасивна конструкція є самим вживаним засобом, складаючи 88,2\% від загального числа прикладів категоріальних засобів вираження пасивності. Прямі пасивні конструкції переважають чисельно, складаючи $62,6 \%$ від загальної кількості категоріальних засобів вираження пасивності в англійській мові кінця XIX - початку XX ст., тобто прямі пасивні конструкції, як і раніше, $\epsilon$ найбільш частотними, але їх кількість зменшилася, за рахунок збільшення кількості інших типів пасивних конструкцій.

В результаті аналізу частотності вживання категоріальних засобів вираження пасивності в сучасній англійській мові кінця XX - початку XXI ст. нами були отримані дані, які свідчать, що пряма пасивна конструкція становить 54,08\% від загального числа прикладів категоріальних засобів вираження пасивності в сучасній англійській мові кінця XX - початку XXI ст., за рахунок збільшення кількості інших типів пасивних конструкцій; кількість прямих пасивних конструкцій зменшилася, але вони як і раніше є самими частотними. 
Таким чином, в ході нашого дослідження, виявлено, що всі типи пасивних конструкцій категоріальних засобів вираження пасивності виявилися досить рухливими.

Необхідно також підкреслити, що в ранній ново англійській мові зустрічаються категоріальні пасивні конструкції всіх типів, це свідчить про вже сформовані пасивні конструкції в зазначений період. Крім того, динаміка змін по тимчасовим відрізкам підтверджує зростання частотності вживання пасивних конструкцій до кінця XIX - початку XX ст. В англійській літературі кінця XX - початку XXI ст. навпаки спостерігається яскраво виражена і досить чітко реалізується тенденція до зниження частки пасиву в дієслівній системі. Також отримані дані представлені в вигляді таблиці 1 (необхідно нагадати, що зазначені числові дані - це відношення кількості прикладів до числа проаналізованих сторінок). Отримані результати дозволяють нам говорити про зміни, що відбулися в системі категоріальних засобів вираження пасивності.

\section{ЛIТЕРАТУРА}

1. Андриевская Л.И. Развитие некоторых типов субъектно-предикативных сочетаний в английском языке: автореф. ... дис. канд. филол. наук: 10.02.04 Л.,1958. $18 \mathrm{c}$.

2. Гусейнов Б.М. Пассив в ранненовоанглийском языке: автореф. дис. ... канд. филол. наук: 10.02.04. Л., 1980. 25 с.

3. Гухман М.М. Становление страдательного залога германских языков и развитие строя предложения (из истории предикативных отношений): автореф. дис. ... докт. филол. наук. М.-Л., Акад. наук СССР, 1950. 53 с.

4. Дмитриева Н.А. Становление и развитие аналитического пассива в английском языке: автореф. дис. ... канд. филол. наук: 10.02.04. М., 1965. 20 с.

5. Сигарева Н.Н. Пассивные конструкции в древнеанглийском языке: дис. ... канд. филол. наук.: 10.02.04. Л., 1984. 160 с.

6. Есперсен О. Философия грамматики. М.,1958. 403 с.

7. Расторгуева Т.А. О методах преподавания пассива в английском языке. Тезисы докладов: конференция по вопросам грамматики германских и романских языков, 17-20 ноября, МГПИИЯ,1959. С.15 - 19.

8. Хвесина М.В. Развитие субъектно- и объектно-предикативных конструкций в английском языке: автореф. дис. ...канд. филол. наук. М., 1973. 29 c.

9. Шавкун И.Г. Развитие семантико-синтаксической сочетаемости глагола в форме страдательного залога (на материале английского языка XIV XVII вв.): дис. ... канд. филол. наук: 00.00.00. Москва, 1984. 166 с.

10.Blokh M.Y. A Course in Theoretical English Grammar. М.: «Высшая школа», 1983. 
11.Bryant, M.M. The Passive Construction. College English. Vol.21, № 4, 1960. P. 230- 232 .

12.Curme G. The Proper Subject of a Passive Verb. M.L.N., 1928. P. 90 - 101.

13.Layons J. Semantics. Cambridge: Cambridge University Press, 1990. Vol. 2. 371p.

14.Palmer P.A. Linguistic Study of the English Verb. L.: University of Miami press, 1968. $199 \mathrm{p}$.

15. Sweet H.A New English Grammar, Logical and Historical. Oxford, 1940. 499 p.

УДК 811.111: $82-9(045)$

DOI: $10.24144 / 2617-3921.2020 .18 .46-55$

Андріана Іванова

кандидат філологічних наук, дочент кафедри англійської філологї ДВНЗ “Ужсгородський національний університет” orcid.org/0000-0002-1733-4416

Ужггород, Україна, +38(066)2256454 andriana.ivanova@uzhnu.edu.ua

\section{Лексичний код жанру літератури жахів у світлі сучасних перекладознавчих розвідок}

Анотаиія. Стаття присвячена дослідженню лексичних особливостей жанру літератури жахів у сучасних перекладознавчих студіях. Окреслено функиіонування лексичного коду в межах жанру літеру тари жахів, а також виокремлено поняття жанротвірного регістру, елементи якого об'єднуються в концептуальні групи. Трьома головними конщептами, що мовно об 'єктивуються у творах жанру, є концепти СМЕРТЬ, ЖАХ, ОГИДА. Концепт СМЕРТЬ реалізується за допомогою когнітеми тварини, щзо пророчать смерть та когнітеми мертве тіло; конщепт ЖАХ мовно об'єктивується когнітемами захоронення ци фізична слабкість; кониепт ОГИДА - когнітемами скалічене й понівечене людське тіло та його органи й кров. Метою иієї статті $\epsilon$ виокремлення домінантних перекладацьких стратегій у відтворенні мовної об'єктивації згаданих вище конщептів. Концепти являють собою частину мовленнєво-розумової діяльності, яка уможливлюе трансляцію вже накопиченого знання в принципово нову ситуацію. Лексичний код жанру нерозривно пов'язаний з предметно-логічним, тематичним, емоційним, образним, сюжетно-композиційним та ідейним 